\title{
The Efficacy of Immediate Implantation of Macroporous Poly(N-[2-Hydroxypropyl]-Methacrylamide) Hydrogel after Laceration Spinal Cord Injury in Young Rats
}

\author{
Eficacia de la Implantación Inmediata de Hidrogel Macroporoso de Poli (N- [2-Hidroxipropil] - \\ Metacrilamida) después de una Lesión de la Médula Espinal en Ratas Jóvenes
}

\author{
Medvediev Volodymyr V. ${ }^{1,2}$; Savosko Serhii I. ${ }^{3}$; Abdallah Ibrahim M. ${ }^{\text {; }}$ Draguntsova Natalya G. ${ }^{4}$; \\ Vaslovych Viktoria V.5; Tsymbaliuk Vitaly I. ${ }^{1,6} \&$ Voitenko Nana V.,
}

MEDVEDIEV, V. V. ; SAVOSKO, S. I. ; ABDALLAH, I. M. ; DRAGUNTSOVA, N. G. ; VASLOVYCH, V. V. ; TSYMBALIUK, V. I. \& VOITENKO, N. V. The efficacy of immediate implantation of macroporous poly(N-[2-hydroxypropyl]-methacrylamide) hydrogel after laceration spinal cord injury in young rats. Int. J. Morphol., 39(6):1749-1757, 2021.

SUMMARY: Spinal cord regeneration after mechanical injury is one of the most difficult biomedical problems. This article evaluates the effect of poly(N-[2-hydroxypropyl]-methacrylamide) hydrogel (PHPMA-hydrogel) on spinal cord regeneration in young rats after lateral spinal cord hemi-excision (laceration) at the level of segments $\mathrm{T}_{12}-\mathrm{T}_{13}$ (TrGel group). The locomotor function score (FS) and the paretic hindlimb spasticity score (SS) were assessed according to Basso-Beattie-Bresnahan (BBB) and Ashworth scales, respectively, and compared to a group of animals with no matrix implanted (Tr group). Regeneration of nerve fibers at the level of injury was evaluated at $\sim 5$ months after spinal cord injury (SCI). One week after the SCI induction, the FS on the BBB scale was $0.9 \pm 0.5$ points in the Tr group and 3.6 \pm 1.2 points in the TrGel group. In the Tr group, the FS in 5 months was significantly lower than in 2 weeks after SCI, while no significant changes in FS were detected in the TrGel group over the entire observation period. The final FS was $0.8 \pm 0.3$ points in the Tr group and $4.5 \pm 1.8$ points in the TrGel group. No significant changes in SS have been observed in the TrGel group throughout the experiment, while the Tr group showed significant increases in SS at 2nd week, 6th week, 3th month and 5th month. The SS in 5 months was $3.6 \pm 0.3$ points on the Ashworth scale in the $\operatorname{Tr}$ group and $1.8 \pm 0.7$ points in the TrGel group. Throughout the observation period, significant differences in FS between groups were observed only in 5 weeks after SCI, whereas significant differences in SS were observed in 2, 3 and 6-8 weeks post-injury. Glial fibrous tissue containing newly formed nerve fibers, isolated or grouped in small clusters, that originated from the surrounding spinal cord matter have been found between the implanted hydrogel fragments. In conclusion, PHPMA-hydrogel improves recovery of the hindlimb locomotor function and promotes regenerative growth of nerve fibers. Further research is needed to clarify the mechanism of this PHPMA-hydrogel effect.

KEY WORDS: Laceration spinal cord injury; PHPMA-hydrogel; Spinal cord regeneration; Locomotor function; Spasticity.

\section{INTRODUCTION}

Spinal cord injury (SCI) is a critical damage of the nerve system that leads to considerable mortality and frequent disability (DeVivo, 2012). According to 2016 epidemiological data, the estimated global annual incidence of SCI reaches $\sim 1$ million cases, and the estimated global prevalence of SCI is 27 million cases (GBD 2016 Traumatic Brain Injury and Spinal Cord Injury Collaborators, 2016). The specific neurological deficit after SCI is caused by neuron death and rupture of nerve fibers at the injury level. If the site of injury is outside the cervical and lumbosacral

\footnotetext{
${ }^{1}$ Department of Neurosurgery, Bogomolets National Medical University, Kyiv, Ukraine.

${ }^{2}$ Department of Sensory Signaling, Bogomoletz Institute of Physiology of National Academy of Sciences of Ukraine, Kyiv, Ukraine.

${ }^{3}$ Department of Histology and Embryology, Bogomolets National Medical University, Kyiv, Ukraine.

${ }^{4}$ Laboratory of Experimental Neurosurgery, The State Institution "Romodanov Neurosurgery Institute, National Academy of Medical Sciences of Ukraine", Kyiv, Ukraine.

${ }^{5}$ Neuropathomorphology Department, The State Institution "Romodanov Neurosurgery Institute, National Academy of Medical Sciences of Ukraine", Kyiv, Ukraine.

${ }^{6}$ Restorative Neurosurgery Department, The State Institution "Romodanov Neurosurgery Institute, National Academy of Medical Sciences of Ukraine", Kyiv, Ukraine.

${ }^{7}$ Department of Biophysics and Molecular Physiology, The State Scientific Institution "Kyiv Academic University", Kyiv, Ukraine.
} 
MEDVEDIEV, V. V. ; SAVOSKO, S. I. ; ABDALLAH, I. M. ; DRAGUNTSOVA, N. G. ; VASLOVYCH, V. V. ; TSYMBALIUK, V. I. \& VOITENKO, N. V. The efficacy of immediate implantation of macroporous poly(N-[2-hydroxypropyl]-methacrylamide) hydrogel after laceration spinal cord injury in young rats. Int. J. Morphol., 39(6):1749-1757, 2021.

spinal cord enlargements, the main goal of restorative treatment is to restore the long supraspinal projections onto motor neurons located below the level of injury. The solution to this problem is associated with the development of biopolymer-based scaffolds which could be implanted in the SCI site (Zhang et al., 2019). One of such scaffolds is macroporous poly (N-[2-hydroxypropyl]-methacrylamide) hydrogel (PHPMA-hydrogel; Woerly et al., 1996, 1998, 1999, 2001a,b,c, 2004; Pertici et al., 2013). Notably, there are only 2 publications evaluating locomotor function in the rat following implantation of this hydrogel into the SCI area (Woerly et al., 2001c; Pertici et al.).

Contusion is certainly the most common type of SCI (Alizadeh et al., 2019); however, practical evaluation of scaffolds in such SCI model is only possible after the glial fibrous scar excision (Woerly et al., 2001c). Therefore, models of spinal cord laceration remain essential for the efficacy studies of most biopolymer-based scaffolds (Alizadeh et al.). Complete spinal cord transection models involve excessive suffering of laboratory animals with no autogenous motor function recovery. Meanwhile, after partial spinal cord transection, in particular following lateral hemisection in rats, considerable autogenous recovery of the motor function has been reported (Mills et al., 2001; Alizadeh et al.). A possible way out of this situation is to use a spinal cord lateral hemi-excision model which is associated with a lower degree of autogenous recovery (Pertici et al.; Zhang et al., 2016). Currently, there is only one publication that addresses the effect of PHPMA-hydrogel on the motor function recovery in the paretic limb using such a model (Pertici et al.). Considering the above and the higher autogenous regeneration potential of the nervous system in young animals (Sutherland \& Geoffroy, 2020), we explored the aspects of motor function recovery following low thoracic spinal cord lateral hemi-excision with immediate PHPMAhydrogel implantation.

\section{MATERIAL AND METHOD}

The study was carried out on non-pedigree albino rats (inbred progeny of Wistar line) obtained from the vivarium of the Bogomoletz Institute of Physiology, aged $\sim 1$ month, weighing $\sim 50 \mathrm{~g}$, kept in permanently ventilated cages at temperatures $\sim 18$ to $22{ }^{\circ} \mathrm{C}$ and a standard duration of the light day, and fed balanced feed formula ad libitum.

Two study groups were formed:

1) the $\operatorname{Tr}$ (trauma) group - lateral hemi-excision of the low thoracic spinal cord fragment, $\sim 1 \mathrm{~mm}$ in length $(\mathrm{n}=8)$;
2) the TrGel (trauma+hydrogel) group - lateral hemiexcision of the low thoracic spinal cord fragment, $\sim 1 \mathrm{~mm}$ in length, followed by immediate filling of the defect with a fragment of amorphous macroporous matrix $(n=6)$.

PHPMA-hydrogel was synthesized by Dr Eric Pinet (FISO Technologies Inc., Quebec, Canada) from N-[2hydroxypropyl]-methacrylamide using radical polymerization with a divinyl cross-linking, as previously described (Woerly et al., 1998), and provided for this project by Dr Yuriy Yaminski. PHPMA-hydrogel is a biocompatible (Woerly et al., 2001c; Pertici et al.) polymer material with a complex spatial structure containing numerous amorphous micro- $(<2 \mathrm{~nm})$, meso- (2 to $50 \mathrm{~nm}$ ) and macropores (50 to $300 \mathrm{~nm}$ ) (Woerly et al., 1999, 2001c).

Injury and PHPMA-hydrogel implantation. Surgical interventions were performed under general anesthesia (intraperitoneal injection of xylazine (Biowet, Poland; 15 $\mathrm{mg} / \mathrm{kg}$ ) and ketamine (Farmak JSC, Ukraine; 70 mg/kg)) using mild aseptic technique. In this and previous studies (Kopach et al., 2017), the injury modeling area was selected by palpation to locate the caudal margin of the rib cage at the site of its attachment to the vertebral column. Considering that the last pairs of ribs are floating (costae fluctuantes in rodents - Olude et al., 2013), and, in theory, less ossified and more flexible in younger animals, and taking into account the lack of special visualization or X-ray verification of the neck parts of ribs and the sites or their attachment to the vertebral column, the laminectomy area can only be described approximately — most likely, at the level of vertebrae $\mathrm{T}_{11}-\mathrm{T}_{12}$, i.e., based on the approximate skeletopy data (Gilerovich et al., 2008; Moonen et al., 2016) adjusted for animal age (Gelderd \& Chopin, 1977; Curless et al., 1977) — at the level of spinal cord segments $\sim \mathrm{T}_{12}-\mathrm{T}_{13}$.

Right-limited laminectomy was performed following a linear skin incision at the $\sim \mathrm{T}_{9}-\mathrm{L}_{2}$ vertebral level and skeletonization of the posterior spinal surface. The dura mater status within the bone window was not determined and the spinal cord was not freed from adjacent nerve trunk prior to inducing a SCI. A longitudinal paramedian incision of the spinal cord along a length of $\sim 1 \mathrm{~mm}$ was made near the left margin of the posterior median artery, and the left half of the spinal cord was cut with ophthalmic scissors at the rostral and caudal ends of the incision. A fragment of the spinal cord within the created defect was removed under the magnification of an operating microscope. Animals in the TrGel group then had PHPMA-hydrogel implanted into the spinal cord defect area (Fig. 1). In both animal groups, the access window to the spinal canal was covered with a fragment of subcutaneous connective tissue removed from the access area, and the soft tissues and skin were sutured 

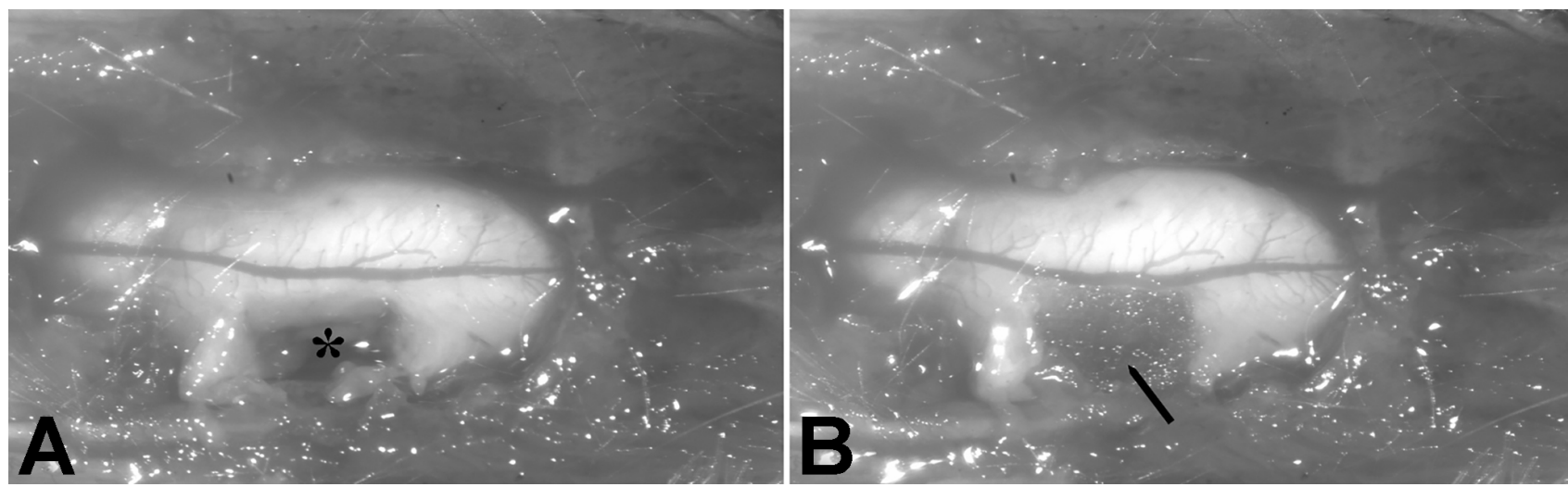

Fig. 1. Stages of the injury and PHPMA-hydrogel implantation model in the TrGel group. Note: a - lateral half of the spinal cord segment excised $(*) ; \mathrm{b}$ - PHPMA-hydrogel implanted in the lesion area $(\rightarrow)$. Intra-operative microphotos.

with two rows of interrupted stitches. To prevent infections and inflammatory complications, animals were administered Bicillin-5 (Kyivmedpreparat JSC, Ukraine) at a dose of $\sim 0.5$ million $\mathrm{U} / \mathrm{kg}$ body weight subcutaneously into the back of the neck and dexamethasone solution (KRKA, Slovenia) at a dose of $\sim 5 \mathrm{mg} / \mathrm{kg}$ body weight intraperitoneally. The rats were subsequently kept in cages of 3 animals each (TrGel) or individual cages (Tr).

The function score (FS) of the hindlimb ipsilateral to the injured area was determined according to the scale proposed by D.M. Basso, M.S. Beattie and J.C. Bresnahan (BBB scale) (Basso et al., 1995), in an own technical modification. The spasticity score (SS) of the hindlimb ipsilateral to the injured area was assessed using the Ashworth scale (Dong et al., 2005) adapted to experimental conditions, in an own technical modification, without acclimation training and relaxation blinding of the animal, while holding the animal horizontally at the caudal end of the body during various types of locomotor behavior. To summarize, the SS was recorded during passive movements in the talocrural joint; 0 points - when there was no resistance; 1 point - slight resistance; 2 points - more marked resistance and preserved movements with quite little effort; 3 points - relatively full passive movements with a quite strong, but not pain-producing effort; 4 point - limited passive movements with non-painproducing effort from the investigator. The following original criteria were used to verify the state of mild spastic paresis ( 0.5 points): limb tremor when pulled to the side by the foot, more pronounced in the paretic hindlimb than in the contralateral limb, and/or hypermetric extension of the paretic limb during postural resistance to sharp tail traction on a horizontal surface. FS and SS were assessed by the same investigator blinded both to individual traits of all animals he/she operated on and to previous FS and SS values. Where there was doubt about the exact integer value of FS or SS, the half value was reported.
Study group non-inclusion criteria were as follows: ipsilateral hindlimb FS of $>9$ points on BBB scale at 1 week post-injury; contralateral hindlimb $\mathrm{FS}$ of $\leq 14$ points on $\mathrm{BBB}$ scale over a long-term observation period. Three animals, 2 of which had bilateral paresis, were excluded from the $\mathrm{Tr}$ group, and 3 animals, 1 of which had bilateral paresis, were excluded from the TrGel group.

If the observation period was reported in weeks, the minimal unit of time was 7 days; if the observation period was reported in months, the minimal unit of time was an interval between the identical dates of the two consecutive months. Individual values of FS and SS at 6 weeks postinjury in both groups were obtained by interpolation as arithmetic means of the respective values in two adjacent observation time points. Asymptotic differences in the actual testing times in study groups were observed at 1 week ( $\sim 29 \%$ from the respective time on the result reporting scale) and 2 weeks $(\sim 7 \%)$; at all other time points, the differences did not exceed $5 \%$.

Histological examination. The animals were sacrificed by overdosing the above anesthetic agents. The spinal cord fragment containing the lesion area was removed and fixated in $\sim 4 \%$ solution of paraformaldehyde in phosphate buffered saline (PBS), pH $7.4(24 \mathrm{~h})$. The $15 \mathrm{~mm}$ thick longitudinal sections of the spinal cord (subjected to freezing at $\sim 15^{\circ} \mathrm{C}$ below zero) were obtained using a microtome-cryostat (MK-25, USSR) and stored in $1 \%$ acidic formalin solution. Silver nitrate impregnation technique was used to detect nerve fibers in the spinal cord matter. Step 1: the sections were placed in pyridine (for $24 \mathrm{~h}$ ) and then rinsed with tap water ( 3 times for 10 minutes each). Step 2: the sections were rinsed with distilled water (3 times for 5 minutes each) and placed in $30 \%$ silver nitrate solution (for $24 \mathrm{~h}$ ). Step 3: the sections were transferred first to distilled water (1 minute), and then sequentially to 
MEDVEDIEV, V. V. ; SAVOSKO, S. I. ; ABDALLAH, I. M. ; DRAGUNTSOVA, N. G. ; VASLOVYCH, V. V. ; TSYMBALIUK, V. I. \& VOITENKO, N. V. The efficacy of immediate implantation of macroporous poly(N-[2-hydroxypropyl]-methacrylamide) hydrogel after laceration spinal cord injury in young rats. Int. J. Morphol., 39(6):1749-1757, 2021.

$1 \%$ acidic formalin solution (3 times for 4 minutes each), ammoniacal silver solution (for $\sim 2$ minutes), $1 \%$ acidic formalin solution until the color changed to orange-brown, then to $0.5 \%$ acidic formalin solution containing $\sim 1-2 \%$ glucose (for 15-20 s), ammonia water (for $~ 30 \mathrm{~s}$ ), and, finally, to distilled water (for 10-15 minutes). The sections were mounted in Canada balsam (Merck, Germany) using $99.8 \%$ isopropanol solution.

Pyridine (Pyridine G.R., 20050-AT0-M1000-1, LachNer, s.r.o., Czech Republic) increases myelin sheath permeability to silver nitrate. All silver nitrate solutions (AgNO 3 , Product Sku 320904; Carlo Erba Reagents S.A.A., France) were prepared and filtered ex tempore. Ammoniacal silver solution was prepared by titrating $30 \%$ solution of silver nitrate with $25 \%$ ammonia solution (Chimlaborreaktiv LLC, Ukraine) until complete dissolution and then filtered. Ammonia water was obtained by adding 5 drops of ammonia per $50 \mathrm{ml}$ of distilled water. All laboratory glassware was made of glass; the sections were transferred between vessels using a glass hook.

Microscope slides were examined under Axiophot microscope (OPTON, Germany) with lens magnifications $\times 2.5, \times 10, \times 20$ and $\times 40$ and photographed with digital camera Canon 600 (CANON INC., Taiwan). The images were calibrated on a computer image analyzer CAI-01ABH (SELMI, Ukraine) using Kappa opto-electronics GmbH software (Germany) and a Carl Zeiss stage micrometer (0.01$1.0 \mathrm{~mm} ; \mathrm{d} \pm 15 \%$ ).

A comparative statistical analysis of the FS and SS values was carried out with STATISTICA 10.0 software package using the Mann-Whitney U Test, the Wilcoxon Matched Pairs Test and the Spearman Rank Order Correlations. Results are expressed as Mean \pm SE. A p-value of $<0.05$ was considered statistically significant.

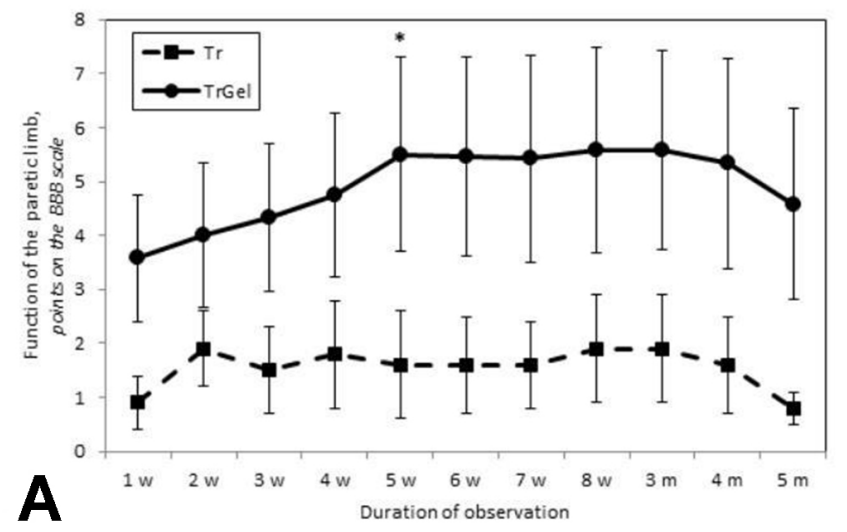

Bioethics. The study was carried out in accordance with EU Council Directive 86/609/EEC “On the Approximation of Laws, Regulations and Administrative Provisions of the Member States Regarding the Protection of Animals Used for Experimental and Other Scientific Purposes" (1986), the European Convention for the Protection of Vertebrate Animals Used for Experimental and Other Scientific Purposes (1999), and Law of Ukraine No. 3447-IV "On the Protection of Animals from Cruel Treatment" (2006). Minutes of Meeting No. 114 of the Bioethics Examination and Research Ethics Committee of the Bogomolets National Medical University dated October 10, 2018.

\section{RESULTS}

The mean FS in the Tr group was $0.9 \pm 0.5$ points on BBB scale in 1 week post-injury (Fig. 2), reached its peak in 2 weeks $(1.9 \pm 0.7$ points on BBB scale; $p>0.05$ versus the first and third week values; Wilcoxon Matched Pairs Test), and subsequently remained near 2 points on BBB scale, regressing to $0.8 \pm 0.3$ points on $\mathrm{BBB}$ scale in $4-5$ months after injury (Fig. 2; $p=0.035$ versus the value at the end of Week 2; Wilcoxon Matched Pairs Test). Throughout the observation period, no correlation was observed between the mean FS in the Tr group and the length of the observation $(r=0.02, p>0.05$; Spearman Rank Order Correlations).

The mean FS in the TrGel group was $3.6 \pm 1.2$ points on BBB scale 1 in week post-injury. This value did not change significantly over the entire observation period $(p>0.05$, Wilcoxon Matched Pairs Test), reached its actual peak (5.6 \pm 1.9 points on BBB scale) in the period from 5th to 12th weeks, and become $4.5 \pm 1.8$ points on $\mathrm{BBB}$ scale at the end of the experiment. No correlation was observed between the mean FS in the TrGel group and the length of the observation $(r=0.57$,

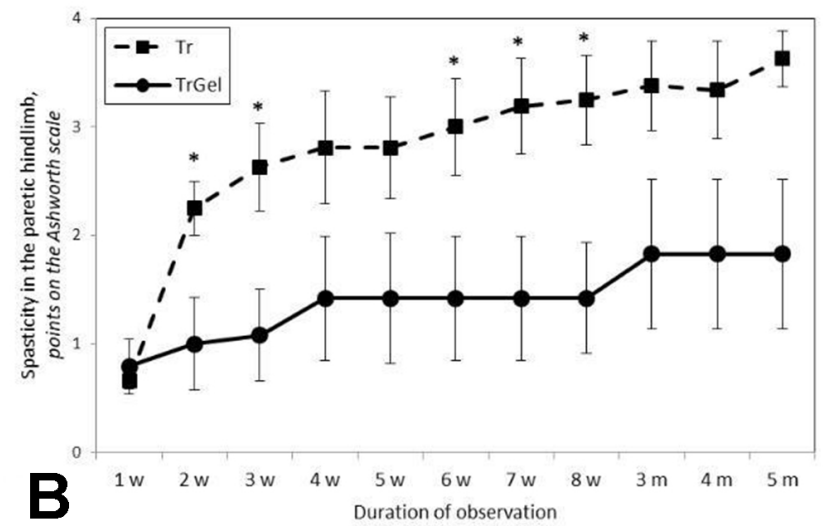

Fig. 2. Changes in FS and SS in the Tr and TrGel groups over the experimental period based on the standardized temporal mesh. Note: a - FS line graph; b - SS line graph; $\mathrm{w}$ - weeks, $\mathrm{m}$ - months, * $-p<0.05$ (Mann-Whitney U Test) 
MEDVEDIEV, V. V. ; SAVOSKO, S. I. ; ABDALLAH, I. M. ; DRAGUNTSOVA, N. G. ; VASLOVYCH, V. V. ; TSYMBALIUK, V. I. \& VOITENKO, N. V. The efficacy of immediate implantation of macroporous poly(N-[2-hydroxypropyl]-methacrylamide) hydrogel after laceration spinal cord injury in young rats. Int. J. Morphol., 39(6):1749-1757, 2021.

p>0.05; Spearman Rank Order Correlations). Significant difference in FS values between the two groups was seen only in 5 weeks after the injury ( $p=0.038$, Mann-Whitney U-Test, Fig. 2a).

The SS in the Tr group was $0.7 \pm 0.1$ points on Ashworth scale in 1 week post-injury (Fig. 2b) and significantly increased to $2.3 \pm 0.3$ points over the subsequent week ( $p=0.01$ versus the first week value; Wilcoxon Matched Pairs Test).
Subsequently, a steady increase in the SS was observed, which was significant ( $p<0.05$; Wilcoxon Matched Pairs Test) at 7 weeks (compared to the value at 2 nd week), at 3 months (compared to the value at $3 \mathrm{~d}$ week), at 4 months (compared to the value at 5 th week), and at 5 months (compared to the values at 5 th and 6th weeks). In other terms differences were not significant. The final SS in the Tr group was $3.6 \pm 0.3$ points on Ashworth scale: 6 out of 8 animals demonstrated maximum SS (4 points on Ashworth scale). There was significant
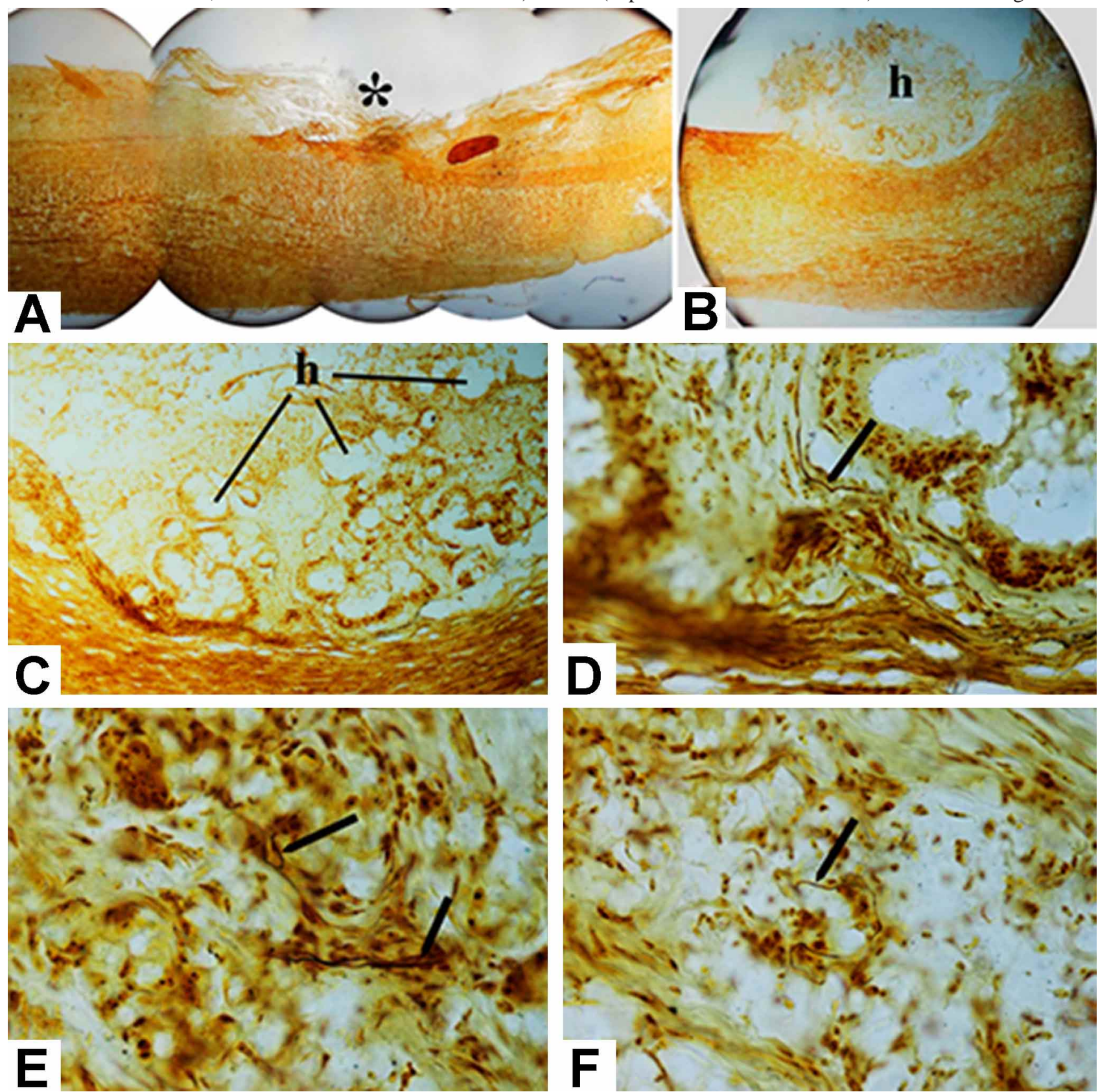

Fig. 3. Regeneration of nerve fibers in the spinal cord laceration area. The nerve fiber is marked with an arrow. Note: a - area of SCI, fibrous tissue in site of hemi-excision (*), figure reconstruction from 4 images obtained at magnification $\times 50$; $b-$ area of SCI with PHPMA-hydrogel (h), a mass of gel in excised site of spinal cord $(\times 50)$; c - newly formed glial fibrous scar around the PHPMA-hydrogel $(¥ 200)$; d, e, f - the same site, nerve fibers $(\rightarrow)$ between PHPMA-hydrogel fragments $(\times 800)$. Silver nitrate impregnation. 
MEDVEDIEV, V. V. ; SAVOSKO, S. I. ; ABDALLAH, I. M. ; DRAGUNTSOVA, N. G. ; VASLOVYCH, V. V. ; TSYMBALIUK, V. I. \& VOITENKO, N. V. The efficacy of immediate implantation of macroporous poly(N-[2-hydroxypropyl]-methacrylamide) hydrogel after laceration spinal cord injury in young rats. Int. J. Morphol., 39(6):1749-1757, 2021.

correlation between the mean SS and the length of observation in this group $(\mathrm{r}=0.99 ; p<0.05$, Spearman Rank Order Correlations).

The mean SS in the TrGel group was $0.8 \pm 0.3$ points on Ashworth scale in 1 week post-injury and changed nonsignificantly over the entire observation period $(p>0.05$, Wilcoxon Matched Pairs Test). The final SS in this group was $1.8 \pm 0.7$ points on Ashworth scale. There was significant correlation between the mean SS and the length of observation in this group $(\mathrm{r}=0.94 ; p<0.05$, Spearman Rank Order Correlations). When comparing SS values between the TrGel group and the Tr group, a significant difference was observed in 2, 3, 6, 7 and 8 weeks after injury $(p<0.05$, Mann-Whitney U Test, Fig.2b).

Both groups showed no correlation between the mean values of FS and SS over the total observation period (Tr group: $r=0.07$; TrGel group: $r=0.58 ; p>0.05$, Spearman Rank Order Correlations). Significant negative correlation between individual values of FS and SS in the Tr group was seen at 5 weeks $(\mathrm{r}=-0.78), 7$ weeks $(\mathrm{r}=-0.81)$ and 8 weeks $(\mathrm{r}=-0.81)$, as well as at 3 months $(\mathrm{r}=-0.92)$ and 4 months $(\mathrm{r}=-0.88)$ post-injury ( $p<0.05$, Spearman Rank Order Correlations). Significant negative correlation between individual values of FS and SS in the TrGel group was seen at all time points except 1 st and 5 th weeks post-injury ( $\mathrm{r}=-0.68$ and $\mathrm{r}=-1.00$, respectively; $p>0.05$, Spearman Rank Order Correlations).

In the site of hemi-excision, an area without white matter, and formed glial fibrous scar was revealed. Regeneration of nerve fibers into injured site of spinal cord was not observed (Fig. 3a). Individual nerve fibers were noticed in the TrGel group in 5 months post-injury. The excised part of the spinal cord was filled withfragments of PHPMAhydrogel surrounded by numerous spindle cells (glial fibrous scar) (Fig. 3b). The scar tissue had a reticular structure and partitioned the PHPMA-hydrogel forming a porous new tissue through which nerve fibers grow (Fig. 3c). The nerve fibers penetrated PHPMA-hydrogel unevenly, as single fibers or in small clusters ( 3 to 6 fibers), they were frequently divergent or even recurrent. The nerve fibers grew in the depth of the glial fibrous scar from adjacent ipsilateral segments (Figs. $3 \mathrm{~d}, \mathrm{e}, \mathrm{f})$. Interestingly, regeneration also occurred through the spinal cord meninges with fibrotic changes above the epicenter of the spinal lesion.

\section{DISCUSSION}

Despite low incidence rate, SCI is a cumulative condition with considerable prevalence, which leads to a substantial worsening in the quality of life of affected patients (DeVivo; GBD 2016 Traumatic Brain Injury and Spinal Cord Injury Collaborators). The main cause of the distinctive neurological deficit after SCI is the damage of the descending nerve fibers in the lesion area which innervate the efferent neurons of the ventral and lateral horns of the spinal cord located below the injury level and the caudal autonomic parasympathetic centers. Tissue processes at the early stage of SCI, which mainly contribute to the low rate of autogenous restoration of the spinal cord function, include primary rupture of nerve fibers, cells and vessels at the lesion epicenter and secondary damage to cells and fibers in the perifocal region due to the development of inflammatory and autoimmune responses (Tran et al., 2018; Alizadeh et al.). Currently, most efforts are directed towards the development of biologically engineered tools for spinal cord function recovery (Zhang et al., 2019). Among the publications on the efficacy of PHPMA-hydrogel (Woerly et al., 1996, 1998, 1999, 2001 a, 2001 b, 2001 c, 2004; Pertici et al.), there is only one study in which lateral hemi-excision was selected as a model of laceration SCI (Pertici et al.), with adult rats as an animal model. The authors implanted a fragment of PHPMA-hydrogel into the site of unilateral onemillimeter spinal cord excision at the $\mathrm{T}_{10}$ level and, following 14 weeks of observation, reported ipsilateral hindlimb FS of $14.29 \pm 1.77$ points on BBB scale versus $8.66 \pm 1.25$ points after SCI without treatment. Our findings have shown that even young animals demonstrated dramatically lower locomotor function recovery scores expressed as FS in the paretic hindlimb after a similar injury induced at the T12-T13 level and subsequent PHPMA-hydrogel implantation: 4.5 \pm 1.8 (TrGel group) vs. $0.8 \pm 0.3$ (Tr group) points on BBB scale in 5 months after injury. Moreover, we intentionally excluded from the analyses all animals with substantial contralateral motor deficit. One possible cause of such inconsistency may be our selection of the exclusion criteria (see above) based on which 1 animal from the Tr group and 2 animals from the TrGel group with FS $>9$ points on BBB scale at 1 week post-injury were excluded from the analyses (these animals had FS of $14,11.5$ and 13 points on BBB scale, respectively). We used this approach to induce the most severe post-SCI motor deficit with ipsilateral localization only, even in the setting of a high autogenous regeneration potential in young animals (Sutherland \& Geoffroy). It appears obvious that the efficacy of any restorative intervention in SCI should be verified on the most severe types of injury while minimizing the suffering of laboratory animals. In our opinion, we were able to achieve this goal in our experiments.

Other differences in study design that could theoretically contribute to the inconsistency between our results and those reported by Pertici et al., include differences in the anesthesia protocol, the use of cold-induced 
MEDVEDIEV, V. V. ; SAVOSKO, S. I. ; ABDALLAH, I. M. ; DRAGUNTSOVA, N. G. ; VASLOVYCH, V. V. ; TSYMBALIUK, V. I. \& VOITENKO, N. V. The efficacy of immediate implantation of macroporous poly(N-[2-hydroxypropyl]-methacrylamide) hydrogel after laceration spinal cord injury in young rats. Int. J. Morphol., 39(6):1749-1757, 2021.

vasoconstriction in the spinal cord tissue the incision of dura mater prior to SCI modeling, the use of adifferent material to isolate the implantation area from covering muscles, the differences in post-operative follow-up and upkeep of animals, and, finally, the differences between laboratory animal lines and levels of trauma. In addition, these authors do not describe what tools were used to verify the completeness of the one-millimeter spinal cord excision intra-operatively and do not specify whether devitalized tissue was removed from the spinal cord wound.

Our findings indicate that PHPMA-hydrogel improves locomotor function recovery following spinal cord lateral hemi-excision (significant improvement observed only in 5 weeks post-injury) and significantly reduces spasticity in the paretic limb (significant reduction in 2 months post-injury). However, as can be seen from Figure 2, most of positive functional effects from PHPMA-hydrogel are formed within the first week after injury, that is, during the most intense inflammatory process in the affected area that defines a secondary spinal cord injury (Alizadeh et al.). One of the obvious reasons underlying this process is the rupture of many small vessels in the lesion epicenter and associated local hemorrhage. According to our observations, PHPMA-hydrogel markedly and rapidly reduces bleeding from the injured spinal cord matter during implantation. We hypothesize that in this way PHPMA-hydrogel reduces the absorption of blood by the adjacent spinal cord matter and reduces direct contact of the spinal cord tissue with cerebrospinal fluid, thus preventing one of the immune response activation pathways. If our hypothesis is correct, this may explain the early beneficial effects of PHPMA-hydrogel.

That being said, the hydrogel implanted in the area of a substantial spatial defect of the spinal cord also has a positive effect in later periods of SCI, probably creating a zone for re-growth of axons through the spatial defect area in the spinal cord. The ingrowth of nerve fibers into the depth of the implanted PHPMA-hydrogel was established by immunohistochemistry for neurofilaments (Woerly et al., 2001a; Pertici et al.). There was strong evidence supporting the longitudinal growth of axons through the PHPMAhydrogel implantation area obtained by axonal tracing (Woerly et al., 2001a,b,c). A non-targeted study using a silver impregnation technique (Woerly et al., 2001b) predictably detected the nerve fiber ingrowth into a PHPMA-hydrogel implanted in the spinal cord lateral hemisection area in a 2day old rat and in an adult rat. Our data indicate that regenerating nerve fibers penetrate the newly-formed reticular tissue in the defect area. The entire defect area was filled with reticular tissue, which is beneficial for the potential growth of nerve fibers. When cystic cavities were formed after the injury and substantial fibrosis made the regeneration of nerve fibers impossible (Woerly et al., 2001a), the newly-formed reticular tissue in PHPMAhydrogel prevented theformation of cavities and allowed lesion site penetration. We believe that this tissue is a complex formed by glial cells and fibroblasts, and morphologically resembles a scar. It has previously been reported that cells surrounding PHPMA-hydrogel express GFAP in the spinal cord and express S-100 and GFAP in cultured fetal neurons and glia, i.e., PHPMA-hydrogel is surrounded by astrocytes (Woerly et al., 1996). The role of astrocytes around PHPMA-hydrogel needs further investigation, as these cells can either interact with PHPMAhydrogel, creating pathways for its penetration by nerve fibers or encapsulate PHPMA-hydrogel as a foreign body. The latter is supported by collagen synthesis around PHPMA-hydrogel (Woerly et al., 1999). Immunohistochemical analyses for myelin basic protein (Woerly et al., 2004) and the detection of myelinated nerve fibers (Woerly et al., 2001c) in the PHPMA-hydrogel indicate that a concomitant axonal remyelination occurs in the scar tissue. Hence, there is no doubt that oligodendrocytes are involved in the formation of the reticular tissue described above. It is important to note that the scar tissue surrounding PHPMA-hydrogel also contains a newly-formed capillary network (Woerly et al., 1998).

Our research also has some traditional limitations for this kind of work. The inability to make a precise skeletopic determination of the level of SCI is the greatest challenge in injury modeling (see above). The main problem with verification tools is the questionable relevance of the $\mathrm{BBB}$ scale in cases of lateral hemi-section or hemi-excision (laceration) of the spinal cord. The relatively intact hindlimb contralateral to the injury is engaged by the animal to compensate for the paretic limb deficit, therefore, in our experience, differentiation between 8 and 9 points can be challenging, and the use of certain criteria, such as weight support of the paretic limb, forelimb-hindlimb coordination and the preferential paw position at the initial contact and lift-off, can be associated with significant difficulties. This means that the scale's verification ability at a level above 8 points in the case of unilateral spinal cord injury is lower than in case of a bilateral, symmetrical deficit. At this stage of research, the negative consequences of the above shortcoming can only be partially compensated for by observing identical methodological and technical rules for FS evaluation in all compared experimental groups. Despite the above, the scale was used to evaluate the locomotor function of the paretic limb after unilateral spinal cord laceration in rats (Mills et al.; Pertici et al.; Zhang et al., 2016; Li et al., 2017). The main issues associated with the use of the Ashworth scale in our modification (see above) are subjective differentiation between the SS degrees from 
1 to 3 points, the inability to exclude a "voluntary" muscle tone in the rats with incomplete paresis, and the inability to identify the "catch" phenomenon due to a small size of the animal's hindlimb. However, we decided to use the Ashworth scale for spasticity verification, because the technically more complex alternative, that is electroneuromyography, has limited informative value and is characterized by a significant variation of individual measurements (Cliffer et al., 1998), probably, due to its inability to precisely detect the paretic muscle motor point in small laboratory animals.

Summarizing, our data show that PHPMA-hydrogel improves recovery of the hindlimb locomotor function and promotes regenerative growth of nerve fibres through the site of spinal cord laceration.

\section{ACKNOWLEDGMENTS}

We thank Dr. Eric Pinet (FISO Technologies Inc., Quebec, Canada) for providing the pHPMA hydrogel, and Dr. Yuriy Yaminski for providing hydrogel for our work.

MEDVEDIEV, V. V. ; SAVOSKO, S. I. ; ABDALLAH, I. M. ; DRAGUNTSOVA，N. G. ; VASLOVYCH， V. V. ; TSYMBALIUK, V. I. \& VOITENKO, N. V. Eficacia de la implantación inmediata de hidrogel macroporoso de poli (N- [2hidroxipropil] -metacrilamida) después de una lesión de la médula espinal en ratas jóvenes. Int. J. Morphol., 39(6):1749-1757, 2021.

RESUMEN: La regeneración de la médula espinal después de una lesión mecánica es uno de los problemas biomédicos más difíciles. Este artículo evalúa el efecto del hidrogel de poli (N- [2-hidroxipropil] -metacrilamida) (PHPMA-hidrogel) sobre la regeneración de la médula espinal en ratas jóvenes después de la hemiescisión lateral de la médula espinal (lesión) a nivel de los segmentos T12 - T13 ( Grupo TrGel). La puntuación de la función locomotora (FS) y la puntuación de espasticidad parética de las patas traseras (SS) se evaluaron de acuerdo con las escalas de BassoBeattie-Bresnahan (BBB) y Ashworth, respectivamente, y se compararon con un grupo de animales sin matriz implantada (grupo Tr). Se evaluó la regeneración de las fibras nerviosas al nivel de la lesión 5 meses después de la lesión de la médula espinal (LME). Una semana después de la inducción de SCI, el FS en la escala BBB fue $0,9 \pm 0,5$ puntos en el grupo Tr y 3,6 $\pm 1,2$ puntos en el grupo TrGel. En el grupo Tr, el FS en 5 meses fue significativamente menor que en 2 semanas después de SCI, mientras que no se detectaron cambios significativos en FS en el grupo TrGel durante el período de observación. El FS final fue de $0,8 \pm 0,3$ puntos en el grupo Tr y de 4,5 $\pm 1,8$ puntos en el grupo TrGel. No se han observado cambios significativos en SS en el grupo TrGel durante el experimento, mientras que el grupo Tr mostró aumentos significativos en SS en la $2^{\mathrm{a}}$ semana, $6^{\mathrm{a}}$ semana, $3^{\circ}$ mes y $5^{\circ}$ mes. La SS en 5 meses fue de 3,6 \pm 0,3 puntos en la escala de Ashworth en el grupo Tr y de $1,8 \pm 0,7$ puntos en el grupo TrGel. A lo largo del período de observación, se observaron diferencias significativas en FS entre los grupos solo en 5 semanas después de la LME, mientras que se observaron diferencias significativas en SS en 2, 3 y 6-8 semanas después de la lesión. Entre los fragmentos de hidrogel implantados se observó tejido fibroso glial que contenía fibras nerviosas recién formadas, aisladas o agrupadas en pequeños grupos, que se originaban a partir de la materia de la médula espinal circundante. En conclusión, PHPMA-hydrogel mejora la recuperación de la función locomotora de las patas traseras y promueve el crecimiento regenerativo de las fibras nerviosas. Se requieren más estudios para aclarar el mecanismo del efecto de hidrogel PHPMA.

PALABRAS CLAVE: Lesión de la médula espinal; PHPMA-hidrogel; Regeneración de la médula espinal; Función locomotora; Espasticidad.

\section{REFERENCES}

Alizadeh, A.; Dyck, S. M. \& Karimi-Abdolrezaee, S. Traumatic Spinal Cord Injury: An Overview of Pathophysiology, Models and Acute Injury Mechanisms. Front. Neurol., 10:282, 2019.

Basso, D. M.; Beattie, M. S. \& Bresnahan, J. C. A sensitive and reliable locomotor rating scale for open field testing in rats. J. Neurotrauma, 12(1):1-21, 1995 .

Cliffer, K. D.; Tonra, J. R.; Carson, S. R.; Radley, H. E.; Cavnor, C.; Lindsay, R. M.; Bodine, S. C. \& DiStefano, P. S. Consistent repeated M- and HWave recording in the hind limb of rats. Muscle Nerve, 1(11):1405-13, 1998

Curless, R. G.; Nelson, M. B.; Brimmer, F. \& Tellez, C. Brain and spinal cord lesions in the newborn rat. Lab. Anim., 11(4):251-5, 1977.

DeVivo, M. J. Epidemiology of traumatic spinal cord injury: trends and future implications. Spinal Cord, 50(5):365-72, 2012.

Dong, H. W.; Wang, L. H.; Zhang, M. \& Han, J. S. Decreased dynorphin A (1-17) in the spinal cord of spastic rats after the compressive injury. Brain Res. Bull., 67(3):189-95, 2005.

GBD 2016 Traumatic Brain Injury and Spinal Cord Injury Collaborators. Global, regional, and national burden of traumatic brain injury and spinal cord injury, 1990-2016: a systematic analysis for the Global Burden of Disease Study 2016. Lancet Neurol., 18(1):56-87, 2019

Gelderd, J. B. \& Chopin, S. F. The vertebral level of origin of spinal nerves in the rat. Anat. Rec., 188(1):45-7, 1977.

Gilerovich, E. G.; Moshonkina, T. R.; Fedorova, E. A.; Shishko, T. T.; Pavlova, N. V.; Gerasimenko, Y. P. \& Otellin, V. A. Morphofunctional characteristics of the lumbar enlargement of the spinal cord in rats. Neurosci. Behav. Physiol., 38(8):855-60, 2008.

Kopach, O.; Medvediev, V.; Krotov, V.; Borisyuk, A.; Tsymbaliuk, V. \& Voitenko, N. Opposite, bidirectional shifts in excitation and inhibition in specific types of dorsal horn interneurons are associated with spasticity and pain post-SCI. Sci. Rep., 7(1):5884, 2017.

Li, L. S.; Yu, H.; Raynald, R.; Wang, X. D.; Dai, G. H.; Cheng, H. B.; Liu, X. B. \& An, Y. H. Anatomical mechanism of spontaneous recovery in regions caudal to thoracic spinal cord injury lesions in rats. PeerJ, 5:e2865, 2017.

Mills, C. D.; Hains, B. C.; Johnson, K. M. \& Hulsebosch, C. E. Strain and model differences in behavioral outcomes after spinal cord injury in rat. J. Neurotrauma, 18(8):743-56, 2001.

Moonen, G.; Satkunendrarajah, K.; Wilcox, J. T.; Badner, A.; Mothe, A.; Foltz, W.; Fehlings, M. G. \& Tator, C. H. A new acute impactcompression lumbar spinal cord injury model in the rodent. $J$. Neurotrauma, 33(3):278-89, 2016 
MEDVEDIEV, V. V. ; SAVOSKO, S. I. ; ABDALLAH, I. M. ; DRAGUNTSOVA, N. G. ; VASLOVYCH, V. V. ; TSYMBALIUK, V. I. \& VOITENKO, N. V. The efficacy of immediate implantation of macroporous poly(N-[2-hydroxypropyl]-methacrylamide) hydrogel after laceration spinal cord injury in young rats. Int. J. Morphol., 39(6):1749-1757, 2021.

Olude, M. A.; Mustapha, O. A.; Ogunbunmi, T. K. \& Olopade, J. O. The vertebral column, ribs, and sternum of the African giant rat (Cricetomys gambianus waterhouse). Sci. World J., 2013:973537, 2013.

Pertici, V.; Amendola, J.; Laurin, J.; Gigmes, D.; Madaschi, L.; Carelli, S.; Marqueste, T.; Gorio, A. \& Decherchi, P. The use of poly(N-[2hydroxypropyl]-methacrylamide) hydrogel to repair a T10 spinal cord hemisection in rat: a behavioural, electrophysiological and anatomical examination. ASN Neuro, 5(2):149-66, 2013.

Sutherland, T. C. \& Geoffroy, C. G. The influence of neuron-extrinsic factors and aging on injury progression and axonal repair in the central nervous system. Front. Cell Dev. Biol., 8:190, 2020.

Woerly, S.; Doan, V. D.; Sosa, N.; de Vellis, J. \& Espinosa-Jeffrey, A. Prevention of gliotic scar formation by NeuroGel allows partial endogenous repair of transected cat spinal cord. J. Neurosci. Res., 75(2):262-72, 2004.

Woerly, S.; Doan, V. D.; Sosa, N.; de Vellis, J. \& Espinosa, A. Reconstruction of the transected cat spinal cord following NeuroGel implantation: axonal tracing, immunohistochemical and ultrastructural studies. Int. J. Dev. Neurosci., 19(1):63-83, 2001a.

Woerly, S.; Petrov, P.; Syková, E.; Roitbak, T.; Simonová, Z. \& Harvey, A. $R$. Neural tissue formation within porous hydrogels implanted in brain and spinal cord lesions: ultrastructural, immunohistochemical, and diffusion studies. Tissue Eng., 5(5):467-88, 1999.

Woerly, S.; Pinet, E.; De Robertis, L.; Bousmina, M.; Laroche, G.; Roitback, T.; Vargová, L. \& Syková, E. Heterogeneous PHPMA hydrogels for tissue repair and axonal regeneration in the injured spinal cord. $J$. Biomater. Sci. Polym. Ed., 9(7):681-711, 1998.

Woerly, S.; Pinet, E.; de Robertis, L.; Van Diep, D. \& Bousmina, M. Spinal cord repair with PHPMA hydrogel containing RGD peptides (NeuroGel). Biomaterials, 22(10):1095-111, 2001b.

Woerly, S.; Plant, G. W. \& Harvey, A. R. Cultured rat neuronal and glial cells entrapped within hydrogel polymer matrices: a potential tool for neural tissue replacement. Neurosci. Lett., 205(3):197-201, 1996.

Woerly, S.; Van Doan, D.; Evans-Martin, F.; Paramore, C. G. \& Peduzzi, J. D. Spinal cord reconstruction using NeuroGelTM implants and functional recovery after chronic injury. J. Neurosci. Res., 66(6):118797, 2001c.

Zhang, Q.; Shi, B.; Ding, J.; Yan, L.; Thawani, J. P.; Fu, C. \& Chen, X. Polymer scaffolds facilitate spinal cord injury repair. Acta Biomater, 88:57-77, 2019.

Zhang, Q.; Yan, S.; You, R.; Kaplan, D. L.; Liu, Y.; Qu, J.; Li, X.; Li, M. \& Wang, X. Multichannel silk protein/laminin grafts for spinal cord injury repair. J. Biomed. Mater. Res. A, 104(12):3045-57, 2016.

\section{Corresponding author: \\ Savosko Serhii, PhD \\ Associate Professor}

Department of Histology and Embryology

Bogomolets National Medical University

T. Shevchenko Boulevard, 13, Kyiv

UKRAINE

E-mail: s.i.savosko@gmail.com

Received: 31-07-2021

Accepted: 06-09-2021 